\title{
FORMULASI DAN UJI AKTIVITAS ANTIOKSIDAN LOTION EKSTRAK DAUN GANDARUSA (Justicia gendarussa Burm $f$.)
}

\author{
Mayaranti Wilsya $^{1}$, Sigit Cahyo Hardiansyah ${ }^{2}$, Desy Pratama Sari ${ }^{3}$ \\ 1,2,3. Program Study SI Farmasi STIK Siti Khadijah Palembang \\ Email : 1stwilsyamaya@gmail.com \\ Sigit.hardiansyahapt@gmail.com
}

\begin{abstract}
ABSTRAK
Indonesia merupakan negara yang beriklim tropis, yang memperoleh sinar matahari lebih banyak yang dapat menyebabkan kerusakan kulit akibat dari pancaran sinar ultraviolet. Perlindungan terhadap paparan langsung sinar matahari yaitu penggunaan sediaan kosmetika yang dapat melindungi kulit agar tidak menjadi kemerahan dan gelap, terasa terbakar atau resiko kanker. Salah satu kosmetik yang dapat digunakan adalah lotion dengan bahan dasar yang diperoleh dari alam yaitu daun gandarusa (Justicia gendarussa Burm f.) yang memiliki kandungan senyawa flavonoid, saponin dan tanin yang berfungsi sebagai antioksidan. Tujuan penelitian ini adalah untuk mengetahui aktivitas ekstrak daun gandarusa (Justicia gendarussa Burm f.) sebagai lotion antioksidan. Penelitian ini merupakan penelitian eksperimental dengan uji karakteristik yang meliputi uji organoleptis, uji daya sebar, uji daya lekat, uji $\mathrm{pH}$, uji homogenitas, uji iritasi dan uji antioksidan. Pada penelitian ini dibuat formulasi lotion dengan konsentrasi ekstrak formula 1 sebanyak $1 \mathrm{gr}$, formula 2 sebanyak $3 \mathrm{gr}$, formula tiga sebanyak $5 \mathrm{gr}$, formula 4 tanpa ekstrak. Data yang diperoleh untuk uji organoleptis formula terbaik adalah formula 4. Pada uji daya sebar yang memenuhi persyaratan yang baik $5-7 \mathrm{~cm}$ hanya formula 1 dan 2 . Pada uji daya lekat formula 4 memenuhi persyaratan yang baik karena menghasilkan daya lekat paling lama dan stabil. Pada uji $\mathrm{pH}$ semua formula memenuhi persyaratan yang baik yaitu 4,5-8,0. Pada uji homogenitas semua formula menunjukkan susunan yang homogen. Pada uji iritasi semua formula tidak menyebabkan iritasi pada kulit. Pada uji antioksidan dengan menggunakan metode DPPH yang memiliki kategori antioksidan sangat kuat yaitu terdapat pada formula 3 dengan antioksidan sebesar 36,05\%. Dari hasil penelitian dapat disimpulkan bahwa ekstrak daun gandarusa dapat diformulasikan menjadi sediaan lotion antioksidan.

\section{Kata kunci}

: Lotion, Antioksidan, daun gandarusa (Justicia gendarussa Burmf.), DPPH.
\end{abstract}

ABSTRACT
Indonesia is a tropical country, which gets more sunlight that can cause skin damage due to ultraviolet rays. Protection against direct exposure to sunlight is the use of cosmetic products that can protect the skin from becoming reddish and dark, burning or the risk of cancer. One of the cosmetics that can be used is lotion with basic ingredients obtained from nature namely gandarusa leaves (Justicia gendarussa Burm f.) which has the content of flavonoid compounds, saponins and tannins that serve as antioxidants. The purpose of this study is to find out the activity of gandarusa leaf extract (Justicia gendarussa Burm f.) as an antioxidant lotion. This research is an experimental study with characteristic tests that include organoleptic testing, scatter power test, ness test, $\mathrm{pH}$ test, homogeneity test, irritation test and antioxidant test. In this study made lotion formulation with extract concentration of formula 1 as much as $1 \mathrm{gr}$, formula 2 as much as $3 \mathrm{gr}$, formula three as much as $5 \mathrm{gr}$, formula 4 without extract. The data obtained for organoleptic testing of the best formula is formula 4. In scatter power tests that meet good requirements $5-7 \mathrm{~cm}$ only formula 1 and 2 . The formula 4 thness test meets good requirements because it produces the most long and stable lys. In the $\mathrm{pH}$ test all formulas meet a good requirement of 4.5-8.0. On the homogeneity test all formulas show a homogeneous arrangement. On the irritation test all formulas do not cause irritation to the skin. In antioxidant test using DPPH method which has a very strong antioxidant category that is found in formula 3 with antioxidants of $36.05 \%$. From the results of the study can be concluded that gandarusa leaf extract can be formulated into an antioxidant lotion.

Keywords : Lotion, Antioxidant, gandarusa leaves (Justicia gendarussa Burmf.),DPPH. 


\section{PENDAhuluan}

Setiap negara memiliki letak wilayah yang memiliki keunikan dan keistimewaan tersendiri salah satunya negara Indonesia. Negara Indonesia jika dilihat dari posisi astronomis terletak dikawasan iklim tropis dan berada di belahan timur bumi. Pergantian musim di Indonesia hanya terjadi dua kali dalam setahun yaitu musim kemarau dan hujan. Karena Indonesia terletak berada di kawasan tropis, ini membuat Indonesia selalu disinari matahari sepanjang tahun. Dalam waktu beberapa bulan terakhir, di Indonesia musim kemarau berlangsung lebih lama dan sinar matahari terasa sangat terik (Arwiyadi F, 2016).

Dalam kehidupan sehari-hari kita tidak dapat menghindarkan paparan sinar matahari, bagaimanapun, tanpa perlindungan yang memadai, sinar matahari sangat dapat merusak kulit selama paparan dalam jangka waktu yang panjang (Baki, 2015). Sinar matahari memiliki peran yang sangat penting bagi kehidupan semua makhluk hidup yaitu sebagai sumber cahaya alami. Selain mempunyai manfaat, sinar matahari juga dapat memberikan efek yang merugikan pada kulit. Indonesia merupakan negara yang beriklim tropis, yang memperoleh sinar matahari lebih banyak yang dapat menyebabkan kerusakan kulit akibat dari pancaran sinar ultraviolet. Paparan sinar ultraviolet dari matahari secara kronik mengakibatkan perubahan struktur, komposisi kulit, dan efek jangka panjang berupa penuaan dini (Putra et al., 2012).

Proses penuaan (aging process) adalah suatu proses alami yang ditandai dengan adanya penurunan atau perubahan kondisi fisik, psikologis maupun sosial dalam berinteraksi dengan orang lain (Handayani dkk, 2013). Seperti negara-negara lainnya di kawasan Asia Pasifik, Indonesia akan mengalami penuaan penduduk dengan cepat. Proporsi penduduk lanjut usia di Indonesia pada tahun 2010 telah mencapai sekitar 10\% (Kemenkes, 2013). Menurut WHO, di kawasan Asia Tenggara populasi lansia sebesar $8 \%$ atau sekitar 142 juta jiwa. Diperkirakan pada tahun 2050 populasi lansia meningkat 3 kali lipat dari tahun 2013. Pada tahun 2000 jumlah Lansia sekitar 5,3 juta $(7,4 \%)$ dari total populasi, sedangkan pada tahun 2010 jumlah Lansia 24 juta $(9,77 \%)$ dari total populasi, dan pada tahun 2020 diperkirakan jumlah Lansia mencapai 28,8 juta $(11,34 \%)$ dari total populasi. Menurut Data Badan Pusat Statistik menunjukkan bahwa penduduk lanjut usia di Indonesia pada tahun 2007 sebanyak 18,7 juta jiwa dan pada tahun 2010 terjadi peningkatan sebesar 23,9 juta jiwa $(9,77 \%)$. Diprediksi pada tahun 2020 jumlah lanjut usia mencapai 28,8 juta jiwa (11,34\%) (Kemenkes RI, 2013). Hal ini akan menyebabkan permasalahan kesehatan terkait penuaan, termasuk didalamnya penuaan kulit yang juga akan meningkat.

Secara alamiah penuaan terjadi pada semua makhluk hidup, tidak terkecuali manusia. Efek dari proses ini adalah terjadinya gangguan fisik. Gangguan secara visual proses penuaan ini adalah terjadi hiperpigmentasi, struktur kulit yang berubah menjadi keriput dan kehilangan elastisitas sehingga menjadi kendur (Mulyawan \& Neti, 2013). Perlindungan terhadap paparan langsung sinar matahari yaitu penggunaan sediaan kosmetika yang dapat melindungi kulit agar tidak menjadi kemerahan dan gelap, terasa terbakar atau resiko kanker kulit (Megantara dkk, 2017). Salah satu jaringan tubuh yang secara langsung memperlihatkan terjadinya proses penuaan yaitu kulit (Cunnningham, 2003; 
dalam Jusuf, 2012). Kulit merupakan organ yang berfungsi melindungi tubuh dari pengaruh buruk yang ada di luar dan yang menutupi seluruh tubuh manusia, sehingga kesehatan kulit perlu dilindungi dan dijaga (Purwaningsih dkk, 2014).

Pada kondisi berlebih, sinar UV dapat menimbulkan beberapa masalah terhadap kulit, seperti kulit kemerahan ,pigmentasi, dan dalam waktu lama menyebabkan resiko kanker kulit (Wungkana, 2013). Pertahun kanker kulit dijumpai 5,9 - 7,8 \% dari semua jenis kanker. Di indonesia kanker kulit yang paling banyak adalah karsinoma sel basal (65,5\%), diikuti karsinoma sel skuamosa (23\%), melanoma maligna $(7,9 \%)$ dan kanker kulit lainnya (Cipto H, 2016). Proses penuaan yang menyebabkan seseorang menjadi tua kemudian menyebabkan sakit karena banyak faktor. Pada dasarnya faktor tersebut ada dua yaitu faktor eksternal dan faktor internal. Faktor eksternal yang utama yaitu pola gaya hidup yang tidak sehat, diet yang tidak sehat, stress dan polusi lingkungan yang meliputi polusi kendaraan bermotor, merokok dan sebagainya. Faktor internalnya adalah genetic, hormon yang berkurang, system kekebalan tubuh yang menurun dan radikal bebas (Pangkahila, 2011).

Radikal bebas merupakan suatu molekul yang memiliki elektron tidak berpasangan dalam orbital terluarnya sehingga sangat reaktif. Jumlah radikal bebas dapat mengalami peningkatan yang diakibatkan dari faktor radiasi, stress, asap rokok dan polusi lingkungan yang menyebabkan sistem pertahanan tubuh yang ada tidak mampu menahan serangan radikal bebas. Untuk mengatasi dan memperlambat penuaan yang diakibatkan oleh radikal bebas, diperlukan suatu formulasi kosmetik yang dapat digunakan secara mudah dan nyaman. Kosmetik yang dapat digunakan berupa bentuk sediaan krim, gel, bedak, losion dan salep (Ardhie, 2011). Salah satu kosmetik yang dapat digunakan untuk itu adalah lotion. Lotion adalah sediaan emulsi yang diaplikasikan secara topikal (Pujiastuti dan Kristiani, 2019). Salah satu senyawa zat aktif yang terkandung dalam lotion adalah antioksidan (Benjamin dkk, 2016). Antioksidan dalam bidang kesehatan, kecantikan dan bahan pangan sangat penting, karena dalam bidang kesehatan antioksidan berfungsi untuk mencegah penyakit degeneratif dan penyakit kanker. Dalam bidang kecantikan antioksidan berfungsi untuk mencegah diri dari penuaan dini (anti aging) dan menjaga kesehatan kulit. Antioksidan dalam bidang pangan digunakan untuk mencegah proses oksidasi yang dapat menyebabkan kerusakan seperti tengik, perubahan aroma, warna dan dapat mencegah peroksidasi lipid pada bahan pangan (Sayuti, 2015). Pengunaan zat-zat yang bersifat antioksidan dapat mencegah berbagai penyakit yang ditimbulkan oleh radiasi sinar UV. Beberapa golongan senyawa aktif antioksidan seperti flavonoid, tannin, antraquinon, sinamat dan lain-lain dilaporkan telah memiliki kemampuan sebagai perlindungan terhadap sinar UV (Putra et al., 2012).

Indonesia merupakan salah satu negara yang memiliki kekayaan alam terbesar di dunia. Namun kekayaan alam tersebut belum dimanfaatkan secara maksimal yang salah satunya terdapat tanaman-tanaman berkhasiat sebagai antioksidan. Salah satu tanaman yang mengandung antioksidan adalah tanaman gandarusa (Justicia gendarussa Burm. f.). Tanaman gandarusa (Justicia gendarussa Burm.f.) merupakan tumbuhan semak yang umumnya tumbuh liar atau ditanaman 
sebagai tanaman obat dan biasa ditemukan di hutan atau tanggul sungai (Andari dan Lastika 2019). Tanaman gandarusa (Justicia gendarussa Burm. $f . \quad$ ) mengandung alkaloid, flavonoid, justicin, minyak atsiri, dan tanin (Rusmiatik, 2013). Suatu tanaman bisa memiliki aktivitas antioksidan apabila tanaman tersebut mengandung senyawa yang dapat menangkal radikal bebas seperti flavonoid. Flavonoid merupakan salah satu senyawa kelompok fenolik yang banyak terdapat dalam jaringan tanaman. Flavonoid bisa berperan sebagai antioksidan (Abdi, 2010). Flavonoid berperan sebagai antioksidan untuk mencegah kerusakan sel dan komponennya oleh radikal bebas (Redha, 2010).

Menurut hasil penelitian Juwita R, daun gandarusa (Justicia gendarussa Burm f.) mempunyai efek analgetik dan anti inflamasi. Namun untuk membuat sediaan lotion antioksidan dari daun gandarusa (Justicia gendarussa Burmf.) belum pernah dilakukan sebelumnya.

\section{METODE PENELITIAN}

\section{ALAT}

Alat yang digunakan dalam penelitian ini meliputi alat-alat gelas, $\mathrm{pH}$ meter, objek glass, rotary evaporator, rak tabung, sentrifuge, spektrofotometri UV- Vis, bejana maserasi, alat uji daya lekat, alat uji daya sebar. neraca analitik, waterbath, mixer, blender, inkubator, kertas perkamen dan tissue.

\section{BAHAN}

Bahan yang digunakan dalam penelitian ini adalah daun gandarusa (Justicia gendarussa Burm f.), asam stearat, TEA, cetyl alkohol, gliserin, etanol 96\%, aquadest, serbuk DPPH, nipagin, minyak zaitun, tween 80, parfum apel dan metanol.

\section{PROSEDUR PENELITIAN}

\section{Pembuatan Simplisia Daun Gandarusa ((Justicia gendarussa Burm f.)}

Sebanyak $2 \mathrm{~kg}$ daun gandarusa (Justicia gendarussa Burmf.) dicuci sampai bersih dengan air yang mengalir dan dipotong kecil-kecil, kemudian dikeringkan dengan cara diangin-anginkan pada suhu ruang dan terhindar dari sinar matahari langsung. Setelah kering lalu diblender dan didapatkan simplisia untuk proses maserasi.

\section{Pembuatan Ekstrak Daun Gandarusa (Justicia gendarussa Burm f.)}

Simplisia daun gandarusa (Justicia gendarussa Burm f.) ditimbang sebanyak 1 $\mathrm{kg}$, dimasukkan kedalam bejana maserasi lalu tambahkan sebanyak 6 liter etanol 96\% dan dimeserasi selama 3 × 24 jam sambil sesekali digojok/diaduk. Kemudian filtrat yang didapat diendapkan selama satu hari, dan lakukan penyaringan dengan menggunakan kapas atau kertas saring. Pisahkan filtratnya dari pelarut pada suhu $70^{\circ} \mathrm{C}$ dengan menggunakan rotary evaporator sehingga didapat ekstrak kental daun gandarusa. 


\section{Pembuatan Lotion}

Formula Lotion Ekstrak Daun Gandarusa (Justicia gendarussa Burmf.)

\begin{tabular}{|l|c|c|c|c|l|}
\hline Bahan & $\begin{array}{l}\text { F1 } \\
\text { (gr) }\end{array}$ & $\begin{array}{l}\text { F2 } \\
\text { (gr) }\end{array}$ & $\begin{array}{l}\text { F3 } \\
\text { (gr) }\end{array}$ & $\begin{array}{l}\text { F4 } \\
\text { (-) }\end{array}$ & Kegunaan \\
\hline $\begin{array}{l}\text { Ekstrak daun } \\
\text { gandarusa }\end{array}$ & 1 & 3 & 5 & - & Zat aktif \\
\hline Asam stearat & 5 & 5 & 5 & 5 & Pengemulsi \\
\hline TEA & 1 & 1 & 1 & 1 & Pengemulsi \\
\hline Minyak zaitun & 20 & 20 & 20 & 20 & Pelembab \\
\hline Cetyl alkohol & 3 & 3 & 3 & 3 & $\begin{array}{l}\text { Stiffening } \\
\text { agent }\end{array}$ \\
\hline Gliserin & 20 & 20 & 20 & 20 & Humektan \\
\hline Tween 80 & 10 & 10 & 10 & 10 & Emulgator \\
\hline Nipagin & 2 & 2 & 2 & 2 & Pengawet \\
\hline Parfum apel & 1 & 1 & 1 & 1 & Pengaroma \\
\hline Aquadest & $\begin{array}{l}\mathrm{Ad} \\
100 \\
\mathrm{~m} 1\end{array}$ & $\begin{array}{l}\mathrm{Ad} \\
100 \\
\mathrm{~m} 1\end{array}$ & $\begin{array}{l}\mathrm{Ad} \\
100 \\
\mathrm{ml}\end{array}$ & $\begin{array}{l}\text { Ad } \\
100 \\
\mathrm{ml}\end{array}$ & Pembawa \\
\hline
\end{tabular}

Lotion dibuat dengan formulasi sesuai dengan yang ditampilkan pada tabel 1 . Tween 80 dan minyak zaitun (Fase I ) dipanaskan diatas waterbath. Kemudian asam stearat dan cetyl alkohol (Fase II ) dipanaskan diatas waterbath. Selanjutnya (Fase III ) TEA, gliserin, nipagin dan sedikit aquadest juga dipanaskan diatas waterbath. Masukkan Fase I dan II kedalam mixer dan dimixer selama 10 menit. Kemudian tambahkan Fase III dan parfum apel dengan pengadukan kontinyu sampai terbentuk emulsi selama 3 menit. Selanjutnya masukkan ekstrak daun gandarusa (Justicia gendarussa Burm f.) dan tambahkan aquadest secara perlahan sampai $100 \mathrm{ml}$.

\section{Evaluasi Sediaan}

\section{Uji Organoleptik}

Uji organoleptic dilakukan dengan pengamatan secara langsung yang meliputi bentuk, warna, dan bau dari lotion.

\section{Uji Daya Sebar}

Uji daya sebar dilakukan dengan cara menimbang sediaan lotion daun gandarusa sebanyak 0,5 gr lalu diletakkan ditengah cawan petri. Diatas sediaan diletakkan lagi cawan petri lain yang telah ditimbang lalu didiamkan selama 1 menit dan dicatat diameter penyebarannya. Tambahkan beban seberat 50 gr diatas cawan petri dan diamkan selama 1 menit lalu catat diameter penyebarannya. Pemberat ditambahkan dengan kelipatan 50 gr hingga mencapai 200 gr, kemudian ukur diameternya dan luas penyebarannya (Pujiastuti A, 2019).

\section{Uji Daya Lekat}

Uji daya lekat dilakukan dengan cara lotion ditimbang sebanyak 0,25 gr diletakkan diatas objek glass yang sudah ditentukan luasnya, kemudian diletakkan objek glass yang lain diatas lotion tersebut dan ditekan selama 5 menit dengan beban $1 \mathrm{~kg}$. Selanjutnya gelas objek dipasang pada alat tes. Dilepas beban seberat 80 gr dan catat waktunya sampai kedua objek glass terlepas (Naibaho dkk, 2013).

\section{Uji Homogenitas}

Uji homogenitas dilakukan dengan menggunakan dua buah kaca objek, dimana sampel diletakkan pada salah satu objek dan letakkan secara merata. Sediaan lotion harus menunjukkan susunan yang homogen (tercampur merata) dan tidak terlihat adanya partikel kasar (Mulyani $\mathrm{T}$ dkk, 2018). 


\section{Uji pH}

Uji $\mathrm{pH}$ dilakukan dengan menggunakan $\mathrm{pH}$ meter. Sediaan diambil sedikit dan encerkan dengan aquadest, kemudian masukkan kertas $\mathrm{pH}$ kedalam sampel dan ukur $\mathrm{pH}$ nya.

\section{Uji Iritasi}

Uji iritasi dilakukan dengan menguji pada 10 panelis untuk mengetahui apakah sediaan lotion yang telah dibuat mengiritasi kulit atau tidak. Uji iritasi terhadap kulit sukarelawan dilakukan dengan uji tempel preventif (patch test). Sejumlah sediaan dioleskan dibelakang daun telinga atau punggung tangan 10 orang sukarelawan dan dibiarkan selama 24 jam, dilihat perubahan yang terjadi (Ditjen POM, 1985). Sediaan dikatakan tidak terjadi iritasi apabila tidak adanya gejala seperti kemerahan, terasa gatal dan memiliki bercak kemerahan.

\section{Cycling Test}

Cycling Test merupakan pengujian yang digunakan untuk melihat kestabilan fisik dari lotion selama 24 jam. Evaluasi karakteristik fisik sediaan lotion meliputi pengamatan organoleptik, uji daya sebar, uji daya lekat, pengujian homogenitas, uji $\mathrm{pH}$, uji iritasi dan uji antioksidan. Pengujian tersebut dianggap sebagai satu siklus dan dilakukan selama 6 hari.

\section{Uji Aktivitas Antioksidan pada Sediaan Pembuatan larutan DPPH}

Sebanyak $50 \mathrm{mg}$ serbuk DPPH dilarutkan dengan menggunakan metanol sebanyak 50 $\mathrm{ml}$.

\section{Penentuan Panjang Gelombang Maksimum}

Sebanyak $1 \mathrm{ml}$ larutan DPPH dimasukkan dalam tabung reaksi. Tambahkan methanol sebanyak $3 \mathrm{ml}$ dan homogenkan.
Dimasukkan kedalam tabung reaksi dan inkubasi selama 30 menit pada suhu $37^{\circ} \mathrm{C}$. Tentukan panjang gelombang maksimumnya dan ukur absorbansinya pada panjang gelombang 500-600 nm.

\section{Pembuatan Larutan Blanko}

Sebanyak $1 \mathrm{ml}$ larutan DPPH ditambahkan dengan $3 \mathrm{ml}$ metanol, gojog hingga homogen dan diamkan selama 30 menit. Ukur absorbansinya pada panjang gelombang maksimum.

\section{Uji Penghambatan Radikal Bebas Pada Sediaan}

Masing-masing formula sediaan ditimbang sebanyak 1,5 gr lalu larutkan dengan $5 \mathrm{ml}$ metanol dan masukkan dalam tabung sentrifuge. Sentrifuge dengan kecepatan 3000 rpm selama 10 menit. Setelah disentrifuge endapan dipisahkan hingga diperoleh larutan uji, kemudian tambahkan $2 \mathrm{ml}$ DPPH dan volumenya dicukupkan hingga $10 \mathrm{ml}$ dengan metanol dalam labu ukur. Masing-masing larutan selanjutnya diukur absorbansinya pada $\lambda$ maksimum yang telah diperoleh sebelumnya.

\section{ANALISA DATA}

Hasil yang diperoleh dari pengamatan sediaan lotion antioksidan daun gandarusa ini berupa data deskriptif dan kuantitatif. Data deskriptif diperoleh dari pengujian organoleptis yang meliputi bentuk, warna dan bau sediaan, uji homogenitas, uji daya sebar dan uji iritasi yang dilakukan setelah pembuatan lotion dengan ditampilkan dalam bentuk tabel dan gambar. Sedangkan data kuantitatif diperoleh dari uji daya lekat, uji $\mathrm{pH}$ dan uji antioksidan lotion. Data kuantitatif dianalisis secara statistik menggunakan excel. 


\section{HASIL DAN PEMBAHASAN}

Setelah dilakukan penelitian mengenai formulasi sediaan lotion daun gandarusa (Justicia gendarussa Burm f.) sebagai antioksidan diperoleh hasil sebagai berikut:

1. Hasil Ekstraksi, Pembuatan simplisia sebanyak $2 \mathrm{~kg}$ daun gandarusa segar yang telah dilakukan proses perajangan didapatkan hasil 1000 gr simplisia. Kemudian dimaserasi dengan 6 liter etanol 96\% selama 3 X 24 jam. Kemudian, pelarut diuapkan dan diperoleh ekstrak kental daun gandarusa segar sebanyak 47,64 gr .

2. Skrining Fitokimia

\begin{tabular}{|c|c|}
\hline Uji Fitokimia & Hasil \\
\hline Alkaloid & - \\
\hline Flavonoid & + \\
\hline Tannin & + \\
\hline Saponin & + \\
\hline
\end{tabular}

- Alkaloid: Pengujian alkaloid ini dilakukan dengan dua jenis reagen yaitu pereaksi mayer dan pereaksi dragendroff dimana didapatkan hasil keduanya negatif karena tidak adanya endapan ataupun pemisahan antara larutan. Hal tersebut kemungkinan terjadi karena kesalahan human error.

- Flavonoid: Pengujian flavonoid dilakukan dengan cara mengambil sebanyak $5 \mathrm{~mL}$ ekstrak dan ditambahkan 0,1 gram serbuk magnesium dan $1 \mathrm{~mL}$ HCL pekat serta $2 \mathrm{~mL}$ etanol, kemudian dikocok dan dibiarkan memisah. Penambahan etanol untuk melarutkan ekstrak dan tujuan penambahan serbuk magnesium dan HCL pekat ini untuk mereduksi ikatan glikosida dengan flavonoid. Agar flavonoid bisa diidentifikasi, maka ikatan glikosida dengan flavonoid dalam tanaman harus diputus dengan cara mereduksi ikatan tersebut yang mana hasil yang didapatkan positif karena terbentuk warna kuning.

- Saponin: Hasil uji fitokimia senyawa saponin dalam penelitian ini yaitu dengan menambahkan $10 \mathrm{~mL}$ air suling dan dikocok selama 10 detik, bila timbul busa ditambahkan HCL 2N. Hasil menunjukkan positif karena busa yang terbentuk dapat bertahan selama 1 menit dengan ketinggian $1 \mathrm{~cm}$.

- Tanin: Hasil penelitian ekstrak daun. gandarusa (Justicia gendarussa Burm f.) menunjukkan adanya senyawa tanin karena terjadi perubahan warna menjadi biru kehitaman yang menandakan adanya senyawa tanin.

\section{Uji Evaluasi Sediaan}

- Hasil uji organoleptis setelah 1 minggu penyimpanan, sediaan lotion dengan variasi perbedaan ekstrak menunjukkan perubahan bentuk dan perubahan bau pada hari ke-2 dan hari ke-3. Bentuk F2 dan F3 terjadi perubahan yang sama yaitu perubahan sama-sama berminyak. Perubahan bau F2 yaitu adanya tambahan bau ekstrak pada sediaan lotion dihari ke-3. Pada F3 bau parfume apel tidak tercium lagi sehingga hanya tercium bau ekstraknya saja. Hal ini terjadi karena lamanya waktu penyimpanan lotion dan basis minyak zaitun yang digunakan dalam sediaan lotion terlalu berlebihan sehingga membuat sediaan lotion menjadi tidak stabil.

- Hasil rata-rata $\mathrm{pH}$ dari keempat formula pada diagram 1 selama satu minggu didapatkan hasil pH netral yaitu 5-6 yang 
berarti sediaan lotion ini memenuhi persyaratan. Perbedaan nilai $\mathrm{pH}$ yang didapat disebabkan karena perbandingan konsentrasi ekstrak daun gandarusa yang berbeda serta pengaruh dari suhu penyimpanan. Hal ini menyatakan bahwa sediaan lotion daun gandarusa yang dihasilkan aman digunakan dimana tidak menimbulkan iritasi kulit.

- Menurut hasil penelitian diketahui bahwa daya sebar dari hari ke-0 sampai hari-ke 6 mengalami perubahan, dan hanya pada F1 dan F2 yang memenuhi range daya sebar yang dipersyaratkan untuk sediaan topikal. Pada F3 dan F4 tidak memenuhi range persyaratan daya sebar karena hasilnya dibawah 5-7 cm. Penambahan beban menghasilkan diameter penyebaran yang semakin besar, sehingga semakin luas juga penyebarannya.

- Uji daya lekat adalah kemampuan melekat sediaan yang merupakan syarat agar lotion dapat digunakan formula 4 menghasilkan daya lekat paling lama dan stabil dibandingkan dengan formula yang lainnya.Perubahan daya lekat yang naik turun dari hari ke hari dipengaruhi oleh waktu lama penyimpanan.

- Hasil pengujian sediaan lotion ini selama satu minggu menunjukkan semua formula homogen.

- semua sediaan lotion tidak menyebabkan iritasi pada kulit karena tidak timbul gejala seperti kemerahan, terasa gatal dan timbul bercak kemerahan.

\section{Uji Antioksidan Sediaan}

Keempat sediaan selanjutnya dilakukan uji antioksidan. Parameter yang digunakan untuk mengetahui besarnya kemampuan senyawa antioksidan yaitu dengan $\mathrm{IC}_{50}$. Sebelum penentuan nilai $\mathrm{IC}_{50}$ dibuat dulu larutan blanko yang berfungsi untuk menghitung persentase inhibisi dan ditetapkan panjang gelombang maksimum terlebih dahulu. Dari hasil penentuan panjang gelombang maksimum yang diperoleh adalah $510 \mathrm{~nm}$. Tujuan penentuan panjang gelombang maksimum adalah untuk mengetahui pada serapan berapa zat dibaca oleh spektrofotometer secara optimum. Masing-masing formula disentrifugasi yang berfungsi untuk memisahkan larutan dengan endapannya. Sentrifugasi dilakukan selama 10 menit dengan kecapatan 3000 ppm. Kemudian diambil filtratnya dan ditambahkan dengan larutan DPPH. Setelah penambahan senyawa uji ke dalam larutan DPPH, sampel diukur absorbansinya masingmasing setiap formula dan terjadi penurunan absorbansi DPPH dibandingkan dengan larutan blanko. Turunnya absorbansi menandakan berkurangnya konsentrasi radikal bebas dari DPPH yang dikarenakan oleh adanya reaksi dengan senyawa antioksidan yang mengakibatkan molekul DPPH tereduksi dan terjadi berkurangnya intensitas warna ungu dari larutan DPPH. Warna dari ungu DPPH berubah menjadi kuning. Setelah itu dilakukan perhitungan nilai IC $_{50}$. Nilai IC $_{50}$ merupakan konsentrasi senyawa antioksidan yang dibutuhkan untuk mengurangi radikal DPPH sebesar 50\%. Hasil yang diperoleh yaitu pada formula I sebesar $60,34 \%$, pada formula 2 diperoleh nilai $\mathrm{IC}_{50}$ sebesar $56,18 \%$, dan pada formula 3 diperoleh sebesar $36,05 \%$. Hasil yang diperoleh dari formula 1 , formula 2 , dan formula 3 berbeda-beda. Hal ini disebabkan karena masing-masing formula memiliki konsentrasi ekstrak yang berbeda. Semakin kecil nilai $\mathrm{IC}_{50}$ maka semakin aktif sediaan tersebut sebagai senyawa pengkap senyawa antioksidan. Dari hasil yang diperoleh sediaan yang memiliki aktivitas antioksidan 
tertinggi yaitu pada formula 3 dengan nilI $\mathrm{IC}_{50}$ sebesar $36,05 \%$.

\section{KESIMPULAN}

Berdasarkan hasil penelitian yang telah diperoleh, dapat disimpulkan bahwa :

1. Senyawa yang terkandung dalam daun gandarusa (Justicia gendarussa Burm f.) adalah flavonoid, tanin, dan saponin.

2. Ekstrak daun gandarusa (Justicia gendarussa Burm f.) dapat diformulasikan dalam sediaan lotion yang bersifat sebagai antioksidan dengan kandungan senyawa kimia flavonoid.

3. Konsentrasi ekstrak daun gandarusa (Justicia gendarussa Burm f.) mempengaruhi karakteristik fisik sediaan lotion yang meliputi uji $\mathrm{pH}$, daya sebar, daya lekat, serta uji antioksidan. Konsentras lotion ekstrak daun gandarusa (Justicia gendarussa Burm $f$.) sebagai antioksidan dengan nilai $\mathrm{IC}_{50}$ terbesar yaitu pada formula 3 sebesar 36,05\% dengan kategori antioksidan sangat kuat. Antioksidan terkecil terdapat pada formula 1 yaitu sebesar $60,34 \%$.

\section{V.SARAN}

Perlu dilakukan penelitian lebih lanjut mengenai manfaat daun gandarusa (Justicia gendarussa Burm f.) selain untuk lotion antioksidan, penggunaan pelarut maupun metode ekstraksi yang lain.

\section{DAFTAR PUSTAKA}

Allen, L. V., Popovich, N.G., Ansel, H.C., 2014. Ansel Bentuk Sediaan Farmasetis \& Sistem Penghantaran Obat, Edisi 9, Penerbit Buku Kedokteran EGC, Jakarta.

Amatullah, L., Cahyaningrum, T., dan Firdaningsih, A. 2017. Efektifitas Antioksidan Pada Formulasi Skin Lotion Ekstrak Mesocarp Buah Lontar (Borassus Flabellifer) terhadap Tikus Putih Jantan Galur Wistar secara In Situ. Akademi Farmasi Nasional Surakarta.

Ardhie, M. A., 2011. Radikal Bebas dan Peran Antioksidan dalam Mencegah Penuaan. Scientific Journal Of Pharmaceutical Development and Medical Application, 24(1), p.4.

Baki, G., dan Alexander, K.S. (2015). Introduction to Cosmetic Formulation and Technology. Nes Jersey: Jhon Wisley \& Sons, Inc. halaman 283, 292.

Cipto H, Suriadiredja AS. Tumor kulit. Dalam: Menaldi SL, Bramono K, Indriatmi W, editor. 2016. Ilmu penyakit kulit dan kelamin. Edisi ketujuh. Jakarta: Badan Penerbit FKUI; 2016. H.262-276.

Departemen Kesehatan RI. 1995. Farmakope Indonesia (Edisi IV). Jakarta: Depkes RI.

Departemen Kesehatan RI. 1985. Formularium Kosmetika Indonesia. Departemen Kesehatan RI. Jakarta. Hal. 23-25.

Departemen Kesehatan RI. 2006. Monografi Ekstrak Tumbuhan Obat Indonesia, Vol.2, 124, Jakarta, Depkes RI.

Ditjen POM, 1985. Formularium Kosmetika Indonesia. Jakarta: Departemen Kesehatan Republik Indonesia. Halaman 22.29 
Djamal, Rusjdi. 2010. Kimia Bahan Alam Prinsip-prinsip Dasar Isolasi dan Identifikasi. Padang: Universitas Baiturrahmah.

Ernawati, Novi. 2011. Stabilitas Fisik Sediaan Lotion Pati Bengkuang (Pachyrhizus erosus L.) dan Aktivitasnya sebagai Tabir Surya pada Mencit. skripsi.Fakultas Farmasi Universitas Gadjah Mada, Yogyakarta.

Faiha, Andari dan Lastika Saraswati. 2019. Sehat dan Bugar dengan Obat Herbal. Yogyakarta: Penerbit Briliant.

Handayani., Dkk. (2013). Pesantren Lansia sebagai upaya meminimalkan Risiko Penurunan Fungsi/Kognitif pada Lansia di Balai Rehabilitasi Sosial Lanjut Usia Unit II Pucang Gading Semarang. Jurnal Keperawatan Komunitas. Vol 1. No 1.

Jannah, R., dan Widodo. "Ekspresi Protein P53 pada Sel TIG -3 Setelah Perlakuan Sinar UV dan Ekstrak Biji Juwet (Syzygium cumini)", Jurnal Biotropika. (Volume 2 No 5, 2014) 273-275.

Kementerian Kesehatan RI. 2013. Gambaran kesehatan lanjut usia di Indonesia. Buletin Jendela Data dan Informasi. 2013;1:9-28

Kementrian Kesehatan Republik Indonesia. 2013. Populasi lansia di perkirakan terus meningkat hingga tahun 2020. Jakarta: Kementrian Kesehatan Republik Indonesia.

Kalangi, Sonny. J.R. 2013. Histofisiologi Kulit. Jurnal Biomedik. 5(3) : 12-20.

Kala'lembang, C. 2016. Kandungan merkuri pada losion pemutih tangan dan badan yang digunakan oleh masyarakat di keluarahan tataaran patar kecamatan tondano selatan kabupaten minahasa. Pharmacon, 5(2). JOUR.

Lisan Fransisca, R. 2015. Penentuan Jenis Tanin secara Kualitatif dan Penetapan Kadar Tanin dari Serabut Kelapa (Cocus nucifera L.) secara Permanganometri. Jurnal Ilmiah Mahasiswa Universitas Surabaya Vol. 4 No. 1 (2015).

Maharani, Ayu. 2015. Penyakit Kulit. Yogyakarta: Pustaka Baru Press.

Marjoni, R. 2016. Dasar-dasar Fitokimia. CV. Trans Info Media: Jakarta Timur.

Megantara, I. N., Megayanti, K., Wirayanti, R., Esa, I. B., Wijayanti, N. P. dan Yustiantara, P.S. 2017. Formulasi Lotion Ekstrak Buah Raspberry (Rubus rosifolius) dengan Variasi Konsentrasi Trietanolamin Sebagai Emulgator Serta Uji Hedonik Terhadap Lotion. Jurnal Farmasi Udayana, 6(1), 3.

Mulyawan, D. \& Neti, S., 2013. A-Z Tentang Kosmetik. Jakarta: PT. Elex Media Komputindo.

Mappaware, Nasrudin Andi. 2016. "ETIKA PENELITIAN (Etika dalam Penelitian Kedokteran - kesehatan)". Jurnal. Fk. umi.

Naibaho, D.H., Yamkan, V, Y., Weni, W., 2013. 'Pengaruh Basis Salep Terhadap Formulasi Sediaan Salep Ekstrak Daun Kemangi (Ocinum sanchum L.) Pada Kulit Punngung Kelinci yang dibuat Injeksi Staphylococcus aureus', Jurnal Ilmiah Farmasi - UNSRAT, 2 No. 02.

Panche, A.N., Diwan, A.D., Chandra, S.R., 2016. Flavonoids : an overview. J. Nutr. Sci. 5, e47. 
Pangkahila, W. 2011. Anti-Aging: Tetap Muda dan Sehat. PT Kompas Media Nusantara. Jakarta.

Pratama, Wiwiek \& Zulkarnain, A.K. 2015. Uji SPF In Vitro dan Sifat Fisik Beberapa Produk Tabir Surya yang Beredar di Pasaran. Majalah Farmaseutik, Vol. 11.

Pujiastuti, Anasthasia., \& Kristiani, Monica. 2019. Formulasi dan Uji Stabilitas Mekanik Hand and Body Lotion Sari Buah Tomat (Licopersicon esculentum Mill.) sebagai Antioksidan'. Jurnal Farmasi Indonesia, 16 (1), 42-55.

Purwaningsih, S., Salamah, E., dan Budiarti, T., A. 2014. "Formulasi Skin Lotion dengan Penambahan Karagenan dan Antioksidan Alami dari Rhizophora mucronata Lamk". Jurnal Akuatika. (Volume V No 1, 2014) 55-62.

Putra, DP \& Susanti, M. 2012. 'Aktivitas perlindungan sinar UV kulit buah Garcinia mangostana Linn secara in vitro', pp. 61-64.

Redha, Abdi. 2010. Flavonoid: Struktur Sifat Antioksidatif dan Peranannya dalam Sistem Biologis. Jurnal berlian N0.2 Hlm 196-202.

Rusmiatik, 2013. Pemberian Ekstrak Daun Gandarusa (Justicia gendarusa burn f.) Menghambat Proses Penuaan Ovarium pada Marmut. Tesis. Denpasar: Universitas Udayana Denpasar.

Salmiyah, S., A.Bahruddin. 2018. Fitokimia dan Antioksidan Pada Buah Tome-tome (Flacourtia Inermis), Hospital Majapahit, 2018: 10 (1): 43-50.

Sayuti, K. \& Yenrina, R., 2015. Antioksidan Alami dan Sintetik, Cetakan I, Jurnal Andalas University Press, Padang.
Sen, S., Chakraborty R. 2011. The role of antioxidant in human health. ACS Symposium Series 1083, 1-37.

Tasmin, N. Erwin, Kusumma, dan Irawan W. 2014. "Identifikasi dan uji toksisitas senyawa flavonoid fraksi kloroform dari daun terap (A. odoratissimus Blanco.)", Jurnal Isolasi, Universitas Mulawarman, 2014.

Tjitrosoepomo, Gembong. 2013. Taksonomi Tumbuhan (Spermatophyta). Yogyakarta : Gadjah Mada University Press.

Uddin R., Wahid M.I., Jesmeen T., Huda N.H., Sutradhar, K.B. 2011. Detection of Formalin in Fish Samples Collected from Dhaka City. Bangladesh. Stamford jurnal of pharmaceutical sciences. 4 (1): 49-52.

Widyaningrum, H. 2011. Kitab Tanaman Obat Nusantara. Yogyakarta: Media Pressindo.

Widyastuti, N. 2010. Pengukuran Aktivitas Antioksidan Dengan Metode CUPRAC, DPPH, dan FRAP Serta Kolerasinya Dengan Fenol dan Flavonoid Pada Enam Tanaman [Skripsi]. FMIPA Institut Pertanian Bogor, Bogor.

Wungkana, I., Suryanto, E., dan Momuat, L. 2013. "Aktivitas Antioksidan dan Tabir Surya Fraksi Fenolik dari Limbah Tongkol Jagung (Zea Mays L.)". Jurnal Ilmiah Farmasi - UNSRAT. (Volume 2 No 04.2013) 149-155

Zulkarnain, A. K., Susanti, M. \& Lathifa, A.N., 2013. Stabilitas Fisik Sediaan Lotion $O / W$ dan $W / O$ Ekstrak Buah Mahkota Dewa Sebagai Tabir Surya dan Uji Iritasi Primer pada Kelinci. Traditional Medicine Journal 18(3). pp. 141-150. 
